\title{
Comparison of Antibacterial Activity of the Spent Substrate of Pleurotus ostreatus and Lentinula edodes
}

\author{
A. Zepeda-Bastida ${ }^{1}$, D. Ojeda-Ramírez ${ }^{1}$, S. Soto-Simental ${ }^{1}$, N. Rivero-Perez ${ }^{1} \&$ M. Ayala-Martínez ${ }^{1}$ \\ ${ }^{1}$ Área Académica de Medicina Veterinaria y Zootecnia, Instituto de Ciencias Agropecuarias, Universidad \\ Autónoma del Estado de Hidalgo, México \\ Correspondence: M. Ayala-Martínez, Área Académica de Medicina Veterinaria y Zootecnia, Instituto de Ciencias \\ Agropecuarias, Universidad Autónoma del Estado de Hidalgo, Avenida Universidad s/n km 1, Tulancingo, \\ Hidalgo, C.P. 43600, México. Tel: 52-771-717-2000 ext. 2449. E-mail: ayalam@uaeh.edu.mx
}

Received: January 21, 2016 Accepted: February 24, 2016 Online Published: March 15, 2016

doi:10.5539/jas.v8n4p43 URL: http://dx.doi.org/10.5539/jas.v8n4p43

\begin{abstract}
Nowadays, the uncontrolled use of antibiotics has created the problem of bacterial resistance to them, what has motivated the search for new alternatives of drug for the treatment of bacterial diseases. Here, we compare antimicrobial activity of spent substrate of mushroom Pleurotus ostreatus and Lentinula edodes, against Escherichia coli, Salmonella tiphymorium, Staphylococcus aureus and Micrococcus luteus. We designed two mixtures, barley straw to be used as a substrate of cultivation of mushroom Pleurotus ostreatus and oats or cedar for the cultivation of mushroom Lentinula edodes; and were obtained aqueous extracts from spent substrates; extracts were tested for antibacterial activity. The protocol was a completely randomized assay with a factorial arrangement design. The data were analyzed with PROC GLM, SAS. The results showed that in the case of Escherichia coli the greatest inhibition zone was of $12.66 \mathrm{~mm}$ at a concentration of $6 \mathrm{mg} \mathrm{mL}^{-1}$, with treatment of Lentinula edodes/Cedar; Salmonella tiphymorium showed a greatest inhibition zone of $31.10 \mathrm{~mm}$ to a concentration of $5.12 \mathrm{mg} \mathrm{mL}^{-1}$, with treatment of Pleurotus ostreatus/Barley straw; Staphylococcus aureus showed a greatest inhibition zone of $9.33 \mathrm{~mm}$ to a concentration of $100 \mathrm{mg} \mathrm{mL}^{-1}$, with the treatment of Lentinula edodes/Cedar and finaly, Micrococcus luteus showed a greatest inhibition zone of $15.00 \mathrm{~mm}$ to a concentration of $50 \mathrm{mg} \mathrm{mL}^{-1}$, with the treatment Lentinula edodes/Oats. In conclusion, the results suggest that it is possible to use indistinctly the spent substrate of Pleurotus ostreatus and Lentinula edodes as source of extracts with antibacterial activity.
\end{abstract}

Keywords: mushroom, Escherichia coli, Salmonella tiphymorium, Staphylococcus aureus and Micrococcus luteus

\section{Introduction}

The uncontrolled use of antibiotics has caused serious problems in human and animal health, causing that bacterias develop resistance to them, so World Health Organization considered to infections caused by bacteria resistant to drugs as a public health problem; therefore, it is necessary to find new pharmacological strategies, among which we can find natural products such as plants and fungi (Roca et al., 2015).

Due to the excess production of agricultural wastes it has increased world production of edible fungi to over 7 million tons, of which $70 \%$ are Basidiomycetes as Agaricus bisporus, Pleurotus ostreatus and Lentinula edodes (Sánchez, 2010; Lin, Ge, \& Li, 2014). Basidiomycetes produce several bioactive substances such as polysaccharides, peptides, nucleosides and phenols which act as hypoglycemic, immunomodulatory, anti-inflammatory, antitumor, antiviral, antibacterial or antiparasitic (Wasser \& Wis, 1999; Wasser, 2002; Sánchez, 2010). By increasing the production of edible mushrooms, also increases accumulation of spent substrate residues after cultivation (Grodzínskaya, Infante, \& Piven, 2002).

Spent mushroom substrate containing carbohydrates as cellulose and hemicellulose, lignin, remnant of edible fungi, is a byproduct of mushroom production industry. Substrate used as growth media to produce mushroom is composed of maize cobs, wheat straw, grass straw, sugarcane bagasse, field hay, corn cobs, cotton seed hulls and some other. After several mushroom harvesting cycles, the productivity of the substrate could decrease so that the substrate is declared as spent (Guoa \& Choroverb, 2006; Onyango, Palapala, Arama, Wagai, \& Gichimu, 2011). One of the main problems in the production of mushrooms still the treatment and disposal of spent 
mushroom substrate; many studies have already been carried out for the use of such substrates, among which we mention feeding and/or antimicrobial activity (Zhu, Sheng, Yan, Qiao, \& Lv, 2012).

The fungi have an important role in the degradation of organic matter (Chang \& Miles, 1984), in addition to being a source of bioactive substances to produce antibiotics or pharmaceutical drugs, such as functional food and additives in feeding stuffs (Santoyo, Ramírez-Anguiano, Reglero, \& Soler-Rivas, 2009). Crop of mushrooms (Pleurotus ostreatus) it is a source of products agricultural, their organic waste generated can be used as a source of food with high protein content and as an alternative pharmaceutical treatment; Pleurotus ostreatus is a fungus that has the ability to grow on agricultural wastes, accelerates the biodegradation and recycling them, avoiding its burning and the subsequent environmental pollution (Varnero, Quiroz, \& Álvarez, 2010). Lentinula edodes, fungi edible, is the most studied, has been shown that fruiting body and mycelium have antimicrobial properties; likewise, the lentine inhibits mycelium growth of other fungi as Physalospora piricola, Mycosphaerella arachidicola and Botrytis cinerea (Rojas, 2013; Romero-Arenas, Martínez, Damian, Ramírez, \& López-Olguín, 2015).

The production of mushroom has been used with a large number of substrates; one of the main is straw, used as a source of carbon to increase the nutritional characteristics and palatability of the fruiting body, getting a better nutritional quality (Sánchez, 2010). The crop of fungi and the quick growth in mushroom production worldwide has resulted in large quantities of spent substrate mushroom (about 13.6 million $t$ year ${ }^{-1}$ ). The massive amounts of waste can cause environmental problems; this causes, led more research to develop technologies for its treatment or use (Lin et al., 2014).

In recent years, there has been a need study antimicrobial phytochemicals with potential to generate new pharmacological options. Our group previously demonstrated that the use of spent substrate of Pleurotus ostreatus mixed or not with medicinal plants, has antibacterial activity (Ayala et al., 2015). Therefore, the objective of this study was to determine the antibacterial activity of spent substrate of Pleurotus ostreatus and/or Lentinula edodes against Escherichia coli, Salmonella tiphymorium, Staphylococcus aureus and Micrococcus luteus at different concentrations.

\section{Method}

\subsection{Strain, Substrates and Cultivation Mushrooms}

The blocks $(1 \mathrm{Kg})$ were obtained from Centro de Investigaciones Biológicas of the Universidad Autónoma del Estado de Hidalgo, México. The blocks were formed by a mixture of barley straw; which were purchased in Central Abastos in Pachuca Hidalgo, Mexico, the taxonomic identification did it the botanist Dr. Miguel Angel Villavicencio Nieto; the specimens were deposited at the Herbarium of the Centro de Investigación de Ciencias Biológicas, of the Universidad Autónoma del Estado de Hidalgo, México. To form the substrate, barley straw was colonized with mycelium of Pleurotus ostreatus UAEH-004 in solid substrate fermentation; mushrooms were harvested at $23 \mathrm{~d}$ and was obtained spent substrate; on the other hand, oats or cedar were colonized with mycelium of Lentinula edodes UAEH-015 in solid substrate fermentation; mushrooms were harvested at $90 \mathrm{~d}$ and were obtained spent substrate of each one.

\subsection{Preparation of Organic Extracts}

The extracts were obtained by mixing $100 \mathrm{~g}$ of spent substrate mushroom of each treatments and $300 \mathrm{~mL}$ distilled water in case of Pleurotus ostreatus and $600 \mathrm{~mL}$ distilled water in case of Lentinula edodes. Then, the mix was macerated in blender during $1 \mathrm{~min}$. Subsequently, mix macerated was filtered using gauze, to separate solid and liquid parts, was filtered through filter paper Whatman ${ }^{\circledR} \# 41$. The extract was placed in a water bath to $70{ }^{\circ} \mathrm{C}$ for $48 \mathrm{~h}$, to obtain the sample dry; for each $25 \mathrm{ml}$ of liquid extract were obtained $0.472 \mathrm{~g}$ of Pleurotus ostreatus and $0.451 \mathrm{~g}$ of Lentinula edodes of dry extract.

\subsection{Colony Forming Units (CFU)}

For obtention of CFU, $100 \mu$ mother sample was placed in $50 \mathrm{ml}$ of nutrient broth and incubated at $37{ }^{\circ} \mathrm{C}$ for 24 $\mathrm{h}$. Subsequently, through serial dilutions of this solution, to concentrations of $10^{-1}, 10^{-2}, 10^{-3}, 10^{-4}, 10^{-5}, 10^{-6}, 10^{-7}$, $200 \mu 1$ were inoculated on plates; Escherichia coli in medium culture Mac Conkey (DIBICO, México), and Salmonella tiphymorium, Staphylococus aureus and Micrococcus luteus in medium culture Estafilococos No. 110 (DIBICO, México), and incubated at $37^{\circ} \mathrm{C}$ for $24 \mathrm{~h}, \mathrm{CFU}$ they were counted.

\subsection{Test Organisms}

The test organisms were Escherichia coli (ATCC25922), Salmonella tiphymorium (ATCC14028), Staphylococcus aureus (ATCC25923) and Micrococcus luteus (ATCC9341). 


\subsection{Antimicrobial Assay}

The antibacterial activity of the spent substrate of Pleurotus ostreatus and/or Lentinula edodes extracts were studied by the method of paper disc diffusion assay with slight modification (Kil et al., 2009). The bacterial pathogens strain were grown in liquid medium for $24 \mathrm{~h}$ to yield a final concentration of Escherichia coli $7.7 \times$ $10^{6} \mathrm{CFU} / 200 \mu \mathrm{L}$, Salmonella tiphymorium $1.11 \times 10^{7} \mathrm{CFU} / 200 \mu \mathrm{L}$, Staphylococus aureus $1.0 \times 10^{7} \mathrm{CFU} / 200 \mu \mathrm{L}$ and Micrococcus luteus $1.04 \times 10^{7} \mathrm{CFU} / 200 \mu \mathrm{L}$. Next, aliquots of $0.1 \mathrm{ml}$ of the test microorganisms were spread over the surface of agar plates. Sterilised filter paper discs of $6 \mathrm{~mm}$ diameter (paper Whatman ${ }^{\circledR} \# 41$ ) were saturated with $50 \mu \mathrm{l}$ of different concentrations $\left(0,6,12.5,25,50\right.$ and $\left.100 \mathrm{mg} \mathrm{mL}^{-1}\right)$ spent substrate of Pleurotus ostreatus and/or Lentinula edodes extracts. The soaked discs were then placed in the middle of the plates and incubated for $24 \mathrm{~h}$ at $37^{\circ} \mathrm{C}$ (Forma Series II Water Jacket $\mathrm{CO}_{2}$, Incubator, Model 3100, Thermo Scientific, USA), after which the diameter (in $\mathrm{mm}$ ) of each inhibitory zone was measured (scalimeter). Negative control was prepared with distilled water; as positive control was used commercial antibiotic (Penicillin G sodium salt, Sigma-Aldrich, St. Louis, MO, USA) to a concentration $100 \mathrm{mg} \mathrm{mL}^{-1}$ on medium culture Mac Conkey and Estafilococos No. 110.

\subsection{Statistical Analysis}

Data were analyzed using factorial design $3 \times 3$ and blocked by extract type and extract concentration and bacterial strain as factors. A PROC GLM procedure and LSMEANS option were used (SAS, 2002).

\section{Results}

Treatment with spent substrate of Pleurotus ostreatus and Lentinula edodes extracts were effective against four bacterial strains tested; antibacterial activity at different concentrations is showed in Table 1; the tested bacteria were quantitatively assessed by measuring the diameter of inhibition generated for each sample; each result is the mean of three replicates. The results showed that the spent substrate Pleurotus ostreatus/Barley straw extracts presented highest inhibitory effect against Escherichia coli $\left(7.7 \times 10^{6} \mathrm{CFU} / 200 \mu \mathrm{L}\right)$ at a concentration of 12.5 $\mathrm{mg} \mathrm{mL}^{-1}$ with $9.86 \mathrm{~mm}$ inhibition halo; Staphylococus aureus $\left(1.0 \times 10^{7} \mathrm{CFU} / 200 \mu \mathrm{L}\right)$ at a concentration of 25 $\mathrm{mg} \mathrm{mL}^{-1}$ with $9 \mathrm{~mm}$ inhibition halo and Micrococcus luteus $\left(1.04 \times 10^{7} \mathrm{CFU} / 200 \mu \mathrm{L}\right)$ at a concentration of 50 $\mathrm{mg} \mathrm{mL}^{-1}$ with $9.66 \mathrm{~mm}$ inhibition halo. Salmonella tiphymorium $\left(1.11 \times 10^{7} \mathrm{CFU} / 200 \mu \mathrm{L}\right)$ at a concentration of $12.5 \mathrm{mg} \mathrm{mL}^{-1}$ with $31.10 \mathrm{~mm}$ inhibition halo, showing significant differences with the concentrations $6,25,50$ and $100 \mathrm{mg} \mathrm{mL}^{-1}(\mathrm{P}<.05)$.

In case of spent substrate Lentinula edodes/Oats extracts, results showed that the highest inhibitory effect against Escheriquia coli $\left(7.7 \times 10^{6} \mathrm{CFU} / 200 \mu \mathrm{L}\right)$ to $12.5 \mathrm{mg} \mathrm{mL}^{-1}$ with $9.20 \mathrm{~mm}$ inhibition halo; Salmonella tiphymorium $\left(1.11 \times 10^{7} \mathrm{CFU} / 200 \mu \mathrm{L}\right)$ to $6 \mathrm{mg} \mathrm{mL}^{-1}$ with $30.30 \mathrm{~mm}$ inhibition halo; Staphylococus aureus $(1.0$ $\left.\times 10^{7} \mathrm{CFU} / 200 \mu \mathrm{L}\right)$ to $50 \mathrm{mg} \mathrm{mL}^{-1}$ with $8.66 \mathrm{~mm}$ inhibition halo and Micrococcus luteus $\left(1.04 \times 10^{7}\right.$ $\mathrm{CFU} / 200 \mu \mathrm{L}$ ) to $50 \mathrm{mg} \mathrm{mL}^{-1}$ with $15 \mathrm{~mm}$ inhibition halo; in this treatment, there was no significatives differences between each of the concentrations tested for each bacteria.

Spent substrate Lentinula edodes/Cedar extracts, results showed the highest inhibitory effect against Escheriquia coli $\left(7.7 \times 10^{6} \mathrm{CFU} / 200 \mu \mathrm{L}\right)$ to $6 \mathrm{mg} \mathrm{mL}^{-1}$ with $12.66 \mathrm{~mm}$ inhibition halo, showing significant differences with the concentrations 12.5, 25, 50 and $100 \mathrm{mg} \mathrm{mL}^{-1}(\mathrm{P}<.05)$ and Salmonella tiphymorium $\left(1.11 \times 10^{7} \mathrm{CFU} / 200 \mu \mathrm{L}\right)$ to $50 \mathrm{mg} \mathrm{mL} \mathrm{m}^{-1}$ with $29.80 \mathrm{~mm}$ inhibition halo, showing significant differences with the concentrations $6,12.5$ and $25 \mathrm{mg} \mathrm{mL}^{-1}(\mathrm{P}<.05)$. The highest inhibitory effect against Staphylococus aureus $\left(1.0 \times 10^{7} \mathrm{CFU} / 200 \mu \mathrm{L}\right)$ was to $100 \mathrm{mg} \mathrm{mL}^{-1}$ with $9.33 \mathrm{~mm}$ inhibition halo and Micrococcus luteus $\left(1.04 \times 10^{7} \mathrm{CFU} / 200 \mu \mathrm{L}\right)$ to $100 \mathrm{mg}$ $\mathrm{mL}^{-1}$ with $10 \mathrm{~mm}$ inhibition halo. Positive control (penicilin) showed larger diameter of inhibition (45 and 30.6 $\mathrm{mm}$ ), than all spent substrate extracts tested. 
Table 1. Antibacterial activity of spent substrate of Pleurotus ostreatus and Lentinula edodes extracts at different concentrations in vitro

\begin{tabular}{|c|c|c|c|c|c|}
\hline \multirow{3}{*}{ Treatment } & \multirow{3}{*}{$\begin{array}{l}\text { Concentration } \\
\left(\mathrm{mg} \mathrm{mL}^{-1}\right)\end{array}$} & \multicolumn{4}{|c|}{ Diameter of inhibition (mm) } \\
\hline & & Escherichia coli & $\begin{array}{l}\text { Salmonella } \\
\text { tiphymorium }\end{array}$ & $\begin{array}{l}\text { Staphylococcus } \\
\text { aureus }\end{array}$ & $\begin{array}{l}\text { Micrococcus } \\
\text { luteus }\end{array}$ \\
\hline & & \multicolumn{4}{|l|}{ Means \pm SD } \\
\hline \multirow[t]{5}{*}{ Pleurotus ostreatus/Barley straw } & 6 & $9.53 \pm 0.40$ & $22.33 \pm 2.51^{\mathrm{c}}$ & 0.00 & 0.00 \\
\hline & 12.5 & $9.86 \pm 0.51$ & $31.10 \pm 8.61^{\mathrm{a}}$ & 0.00 & 0.00 \\
\hline & 25 & $9.46 \pm 0.68$ & $26.96 \pm 10.01^{b}$ & $9.00 \pm 1.00$ & 0.00 \\
\hline & 50 & $9.10 \pm 1.05$ & $24.63 \pm 5.22^{\mathrm{b}}$ & $8.86 \pm 1.69$ & $9.66 \pm 1.52$ \\
\hline & 100 & $9.00 \pm 1.17$ & $20.50 \pm 3.43^{c}$ & $8.36 \pm 0.71$ & $8.83 \pm 1.25$ \\
\hline \multirow[t]{5}{*}{ Lentinula edodes/Oats } & 6 & $8.83 \pm 1.04$ & $30.30 \pm 2.30$ & 0.00 & 0.00 \\
\hline & 12.5 & $9.20 \pm 0.72$ & $29.60 \pm 4.35$ & 0.00 & 0.00 \\
\hline & 25 & $8.50 \pm 0.50$ & $29.40 \pm 2.02$ & 0.00 & 0.00 \\
\hline & 50 & $8.06 \pm 1.32$ & $28.76 \pm 3.99$ & $8.66 \pm 1.15$ & $15.00 \pm 2.29$ \\
\hline & 100 & $8.83 \pm 0.28$ & $27.66 \pm 3.78$ & $8.33 \pm 1.52$ & $12.00 \pm 1.80$ \\
\hline \multirow[t]{5}{*}{ Lentinula edodes/Cedar } & 6 & $12.66 \pm 2.88^{\mathrm{a}}$ & $27.83 \pm 1.44^{\mathrm{b}}$ & 0.00 & 0.00 \\
\hline & 12.5 & $8.66 \pm 0.35^{\mathrm{b}}$ & $26.00 \pm 1.00^{\mathrm{b}}$ & 0.00 & $9.33 \pm 0.57$ \\
\hline & 25 & $10.10 \pm 1.92^{\mathrm{b}}$ & $28.46 \pm 5.68^{\mathrm{b}}$ & $8.66 \pm 0.57$ & $9.66 \pm 1.15$ \\
\hline & 50 & $7.83 \pm 1.61^{\mathrm{b}}$ & $29.80 \pm 1.55^{\mathrm{a}}$ & $8.43 \pm 1.40$ & $9.66 \pm 1.52$ \\
\hline & 100 & $8.80 \pm 1.85^{\mathrm{b}}$ & $29.46 \pm 3.99^{\mathrm{a}}$ & $9.33 \pm 1.15$ & $10.00 \pm 1.00$ \\
\hline Penicilin & 100 & $30.6 \pm 3.05$ & $45.00 \pm 0.00$ & $45.00 \pm 0.00$ & $45.00 \pm 0.00$ \\
\hline
\end{tabular}

Note. ${ }^{\text {abc }}$ Literal different ranks indicate significant difference between the concentrations of each treatment $(\mathrm{P}<$ $0.05)$ with the Tukey test.

When comparing the largest zone of inhibition of the three treatments tested (Pleurotus ostreatus/Barley straw, Lentinula edodes/Oats y Lentinula edodes/Cedar) against each bacteria (Table 2), the results showed in the case of Escherichia coli the largest zone of inhibition was at a concentration of $6 \mathrm{mg} \mathrm{mL}^{-1}(12.66 \mathrm{~mm})$ with treatment of Lentinula edodes/Cedar; Salmonella typhimurium showed the largest zone of inhibition at a concentration of $5.12 \mathrm{mg} \mathrm{mL}^{-1}(31.10 \mathrm{~mm})$ with treatment of Pleurotus ostreatus/Barley straw; Staphylococcus aureus showed the largest zone of inhibition at a concentration of $100 \mathrm{mg} \mathrm{mL}^{-1}(9.33 \mathrm{~mm})$ with the treatment of Lentinula edodes/Cedar and Micrococcus luteus showed the largest zone of inhibition at a concentration of $50 \mathrm{mg} \mathrm{mL}$ $(15.00 \mathrm{~mm})$ with treatment of Lentinula edodes/Oats. Salmonella typhimurium and Staphylococcus aureus no showed significant differences between each treatments; Escherichia coli treated with Lentinula edodes/Oats is significantly different to the treatment Lentinula edodes/Cedar $(\mathrm{P}<0.05)$, but without showing difference significant with treatment Pleurotus ostreatus/Barley straw, while Micrococcus luteus treated with Lentinula edodes/Oats is significantly different with treatment of Lentinula edodes/Cedar and Pleurotus ostreatus/Barley straw $(\mathrm{P}<0.05)$. 
Table 2. Comparison of antibacterial activity of spent substrate of Pleurotus ostreatus and Lentinula edodes extracts against Escheriquia coli, Salmonella tiphymorium, Staphylococus aureus and Micrococcus luteus in vitro.

\begin{tabular}{|c|c|c|c|c|c|c|}
\hline \multirow{3}{*}{ Bacteria } & \multicolumn{2}{|c|}{ Pleurotus ostreatus/Barley straw } & \multicolumn{2}{|c|}{ Lentinula edodes/Oats } & \multicolumn{2}{|c|}{ Lentinula edodes/Cedar } \\
\hline & \multirow{2}{*}{$\begin{array}{l}\text { Concentration } \\
\left(\mathrm{mg} \mathrm{mL}^{-1}\right)\end{array}$} & $\begin{array}{l}\text { Diameter of } \\
\text { inhibition }(\mathrm{mm})\end{array}$ & \multirow{2}{*}{$\begin{array}{l}\text { Concentration } \\
\left(\mathrm{mg} \mathrm{mL}^{-1}\right)\end{array}$} & $\begin{array}{l}\text { Diameter of } \\
\text { inhibition }(\mathrm{mm})\end{array}$ & \multirow{2}{*}{$\begin{array}{l}\text { Concentration } \\
\left(\mathrm{mg} \mathrm{mL}^{-1}\right)\end{array}$} & $\begin{array}{l}\text { Diameter of } \\
\text { inhibition }(\mathrm{mm})\end{array}$ \\
\hline & & Means \pm SD & & Means \pm SD & & Means \pm SD \\
\hline E. coli & 12.5 & $9.86 \pm 0.51^{\mathrm{a}}$ & 12.5 & $9.20 \pm 0.72^{b}$ & 6 & $12.66 \pm 2.88^{\mathrm{a}}$ \\
\hline S.tiphymorium & 12.5 & $31.10 \pm 8.61$ & 6 & $30.30 \pm 2.30$ & 50 & $29.80 \pm 1.55$ \\
\hline S. aureus & 25 & $9.00 \pm 1.00$ & 50 & $8.66 \pm 1.15$ & 100 & $9.33 \pm 1.15$ \\
\hline M.luteus & 50 & $9.66 \pm 1.52^{\mathrm{b}}$ & 50 & $15.00 \pm 2.29^{\mathrm{a}}$ & 100 & $10.00 \pm 1.00^{\mathrm{b}}$ \\
\hline
\end{tabular}

Note. $^{\text {ab }}$ Literal different ranks indicate significant difference between treatments of each bacteria $(\mathrm{P}<0.05)$ with the Tukey test.

\section{Discussion}

In recent years the bacteria have acquired the ability of multi-resistance to antibiotics (Nehra, Meenakshi, \& Yadav, 2012) which has generated that recent research are focus in the search for alternative treatments, such as fungi. Edible fungi such as Pleurotus ostreatus, have shown a high nutritional value as food (Patel, Naraian, \& Singh, 2012) and anti-inflammatory, antidiabetic, antiviral, antioxidant, anticancer, antitumor, inmunomodulatory and antibacterial activity; however, most of the research has been based on the study of the fruiting body and not in spent substrate (Hearst et al., 2009; Deepalakshmi \& Mirunalini, 2014).

A water-soluble polysaccharide named PL was isolated and purified from spent mushroom substrate, the polysaccharide contained two fractions (PL1 and PL2), composed of glucose, rhamnose and mannose; the antibacterial activity of polysaccharide against $E$. coli was the strongest, while the weakest against Sarcina lutea, the minimal inhibition concentrations of PL2 were 12.5, 25 and $100 \mu \mathrm{g} / \mathrm{mL}$, respectively (Zhu et al., 2012). We show that aqueous extract of spent substrate of Pleurotus ostreatus/Barley straw has antibacterial activity against Escherichia coli $(9.86 \mathrm{~mm})$, Staphylococcus aureus $(9.00 \mathrm{~mm})$, Micrococcus luteus $(9.66 \mathrm{~mm})$ and Salmonella tiphymorium $(31.10 \mathrm{~mm})$, similar to that obtained using extracts of mushroom Pleurotus ostreatus obtained with different organic solvents (24.56 and $14 \mathrm{~mm}$ ) for Gram positive and Gram negative bacteria (Nehra et al., 2012).

For the cultivation of Lentinula edodes for many years have used various agricultural and industrial wastes, among which we mention sorghum, sugar cane, sawdust, oak, cedar (Grodzínskaya et al., 2002) as carbon source; shiitake mushrooms (Lentinus edodes) is of great importance, due to its attributed not only to its nutritional value, but also potential applications in industrial food and medicine as antibacterial (Hearst et al., 2009) and/or antitumor, among other features; this activity is due to the lentina (one polysaccharide isolated from fruiting body), which acts as an enhancer of host defense; has shown action against Staphylococcus aureus, Bacillus subtilis and Escherichia coli (Hatvani, 2001). Chowdhury, Kubrai, and Ahmed (2015) mentioned antimicrobial activity of 3 edible mushrooms (Pleurotus ostreatus, Lentinula edodes, Hypsizigus tessulatus) methanolic extracts, indicated considerable activity against bacteria and fungi, reveling zone of inhibition ranged from $7 \pm 0.2$ to $20 \pm 0.1 \mathrm{~mm}$; Kazue, Megumi, and Dantas (2001) found that the mycelium of 35 different strains of Lentinus edodes, has antibacterial activity against $B$. subtilis, with inhibition halos 5-20 mm in diameter similar to our findings.

This work is novel because for the first time is studied the use of spent substrate Lentinula edodes as antibacterial, since only been shown this activity in the fruiting body; they have been used different extraction techniques: high-pressure operations and low-pressure methods. The high-pressure technique was applied to obtain Lentinus edodes extracts using pure $\mathrm{CO}_{2}$ and $\mathrm{CO}_{2}$ with co-solvent or organic solvents such as n-hexane, ethyl acetate and dichloromethane (Kitzberger, Smânia Jr., Pedrosa, \& Ferreira, 2007); here it is included barley straw as a substrate for the cultivation of Pleurotus ostreatus and oats or cedar for the cultivation of Lentinula edodes, in order to obtain aqueous extracts and determine its antibacterial activity; the findings suggest that it is feasible to use these substrates in the future for obtain antibacterial pharmaceutical compounds and at the same time reduce the pollution by their accumulation. 


\section{References}

Ayala, M. M., Ojeda, D. R., Soto, S. S., Rivero, N. P., Meneses, M. M., \& Zepeda-Bastida, A. (2015). Antibacterial activity of spent substrate of mushroom Pleurotus ostreatus enriched with herbs. Journal of Agricultural Science, 7, 225-231. http://dx.doi.org/10.5539/jas.v7n11p225

Chang, S. T., \& Miles, P. G. (1984). A new look at cultivated mushrooms. BioScience, 34, $358-362$. http://dx.doi.org/10.2307/1309726

Chowdhury, M., Kubra, K., \& Ahmed, S. (2015). Screening of antimicrobial, antioxidant properties and bioactive compounds of some edible mushrooms cultivated in Bangladesh. Annals of Clinical Microbiology and Antimicrobials, 14, 8. http://dx.doi.org/10.1186/s12941-015-0067-3

Deepalakshmi, K., \& Mirunalini, S. (2014). Pleurotus ostreatus: An oyster mushroom with nutritional and medicinal properties. Journal of Biochemical Technology, 5, 718-726.

Grodzínskaya, A. A., Infante, D. H., \& Piven, N. M. (2002). Cultivo de hongos comestibles utilizando desechos agrícolas e industriales. Agronomía Tropical, 52, 427-447. Retrieved from http://www.scielo.org.ve/scielo.php?script=sci_arttext\&pid=S0002-192X2002000400002\&lng=es\&tlng=es

Guoa, M., \& Choroverb, J. (2006). Leachate migration from spent mushroom substrate through intact and repacked subsurface soil columns. Waste Management, 26, 133-140. http://dx.doi.org/10.1016/j.wasman.2004.12.024

Hatvani, N. (2001). Antibacterial effect of the culture fluid of Lentinus edodes mycelium grown in submerged liquid culture. International Journal of Antimicrobial Agents, 17, 71-74. http://dx.doi.org/10.1016/S0924-8579(00)00311-3

Hearst, R., Nelson, D., McCollum, G.., Millar, B. C., Maeda, Y., ... Moore, J. E. (2009). An examination of antibacterial and antifungal properties of constituents of Shiitake (Lentinula edodes) and Oyster (Pleurotus ostreatus) mushrooms. Complementary Therapies in Clinical Practice, 15, 5-7. http://dx.doi.org/10.1016/j.ctcp.2008.10.002

Kazue, N. I., Megumi, M. C. K., \& Dantas, M. C. V. (2001). Antibacterial activity of Lentinula edodes grown in liquid medium. Brazilian Journal of Microbiology, 32, 206-210. http://dx.doi.org/10.1590/S1517-83822001000300008

Kil, H. Y., Seong, E. S., Ghimire, B. K., Chung, I. M., Kwon, S. S., \& Goh, E. J. (2009). Antioxidant and antimicrobial activities of crude sorghum extract. Food Chemistry, 115, 1234-1239. http://dx.doi.org/10.1016/j.foodchem.2009.01.032

Kitzberger, C. S. G., Smânia Jr., A., Pedrosa, R. C., \& Ferreira, S. R. S. (2007). Antioxidant and antimicrobial activities of shiitake (Lentinula edodes) extracts obtained by organic solvents and supercritical fluids. Journal of Food Engineering, 80, 631-638. http://dx.doi.org/10.1016/j.jfoodeng.2006.06.013

Lin, Y., Ge, X., \& Li, Y. (2014). Solid state anaerobic co-digestion of spent mushroom substrate with yard trimmings and wheat straw for biogas production. Bioresource Technology, 169, 468-474. http://dx.doi.org/10.1016/j.biortech.2014.07.020

Nehra, K., Meenakshi, M. K., \& Yadav, A. (2012). Evaluation of antimicrobial potential of fruiting body extracts of Pleurotus ostreatus (oyster mushroom). International Journal of Microbial Resource Technology, 1, 391-400. Retrieved from http://ijmrt.inpressco.com ISSN 2278-3822

Onyango, B. O., Palapala, V. A., Arama, P. F., Wagai, S. O., \&Gichimu, B. M. (2011). Suitability of selected supplemented substrates for cultivation of Kenyan native wood ear mushrooms (Auricularia auricula). American Journal of Food Technology, 6, 395-403. http://dx.doi.org/10.3923/ajft.2011.395.403

Patel, Y., Naraian, R., \& Singh, V. K. (2012). Medicinal Properties of Pleurotus Species (Oyster Mushroom): A Review. World Journal of Fungal and Plant Biology, 3, 01-12. Retrieved from http://www.idosi.org/wjfpb/wjfpb3(1)12/1.pdf

Roca, I., Akova, M., Baquero, F., Carlet, J., Cavaleri, M., Coenen, S., .... Vila, J. (2015). The global threat of antimicrobial resistance: science for intervention. New Microbes and New Infections, 6, 22-29. http://dx.doi.org/10.1016/j.nmni.2015.02.007

Rojas, R. L. (2013). Los Basidiomicetos: Una herramienta biotecnológica promisoria con impacto en la agricultura. Fitosanidad, 17, 49-55. Retrieved from http://www.redalyc.org/articulo.oa?id=209128776009 
Romero-Arenas, O., Martínez, M. A. G., Damian, M. A. H., Ramírez, B. V., \& López-Olguín, J. F. (2015). Producción del hongo Shiitake (Lentinula edodes Pegler) en bloques sintéticos utilizando residuos agroforestales. Revista Mexicana de Ciencias Agrícolas, 6, 1229-1238.

Sánchez, C. (2010). Cultivation of Pleurotus ostreatus and other edible mushrooms. Applied Microbiology and Biotechnology, 85, 1321-1337. http://dx.doi.org/10.1007/s00253-009-2343-7

Santoyo, S., Ramírez-Anguiano, A., Reglero, G., \& Soler-Rivas, C. (2009). Improvement of the antimicrobial activity of edible mushroom extract by inhibition of oxidative enzymes. International Journal of Food Science \& Technology, 44, 1057-1064. http://dx.doi.org/10.1111/j.1365-2621.2008.01896.x

SAS Institute Inc. (2002). SAS User's guide: Stat, version 6.03. SAS Institute Inc., Cary, NC, USA.

Varnero, T. M., Quiroz, M. S., \& Álvarez, C. H. (2010). Utilización de residuos forestales lignocelulósicos para producción del hongo ostra (Pleurotus ostreatus). Información Tecnológica, 21, 13-20. http://dx.doi.org/10.4067/S0718-07642010000200003

Wasser, S. P. (2002). Medicinal mushrooms as a source of antitumor and immunomodulating polysaccharides. Applied Microbiology and Biotechnology, 60, 258-274. http://dx.doi.org/10.1007/s00253-002-1076-7

Wasser, S. P., \& Wis, A. L. (1999). Medicinal properties of substances occurring in higher Basidiomycetes mushrooms: Current perspectives (Review). International Jounal of Medicinal Mushrooms, 1, 31-62. http://dx.doi.org/10.1615/IntJMedMushrooms.v1.i1.30

Zhu, H., Sheng, K., Yan, E., Qiao, J., \& Lv, F. (2012). Extraction, purification and antibacterial activities of a polysaccharide from spent mushroom substrate. International Journal of Biological Macromolecules, 50, 840-843. http://dx.doi.org/10.1016/j.ijbiomac.2011.11.016

\section{Copyrights}

Copyright for this article is retained by the author(s), with first publication rights granted to the journal.

This is an open-access article distributed under the terms and conditions of the Creative Commons Attribution license (http://creativecommons.org/licenses/by/3.0/). 